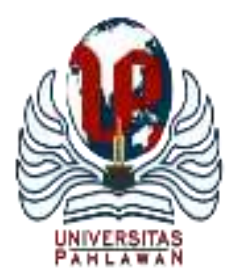

\title{
JURNALBASICEDU
}

Volume 5 Nomor 6 Tahun 2021 Halaman 6196 - 6210

Research \& Learningin Elementary Education

https://jbasic.org/index.php/basicedu

\section{Pengembangan Lembar Kerja Peserta Didik (LKPD) Berbasis Proyek pada Materi Siklus Air Kelas V Sekolah Dasar}

\author{
Arie Widya Murni ${ }^{1 凶}$, Fajar Nur Yasin ${ }^{2}$ \\ Pendidikan Guru Sekolah Dasar, Universitas Nahdlatul Ulama Sidoarjo, Indonesia ${ }^{1,2}$ \\ E-mail: ariewidya.pgsd@ unusida.ac.id ${ }^{1}$, fajarnuryasin.pgsd@unusida.ac.id $^{2}$
}

\begin{abstract}
Abstrak
Penelitian pengembangan ini bertujuan menjelaskan kevalidan, kepraktisan dan keefektifan lembar kerja peserta didik berbasis proyek untuk meningkatkan hasil belajar siswa kelas V sekolah dasar. Penelitian pengembangan ini menggunakan model ADDIE (Analysis, Design, Development, Implementation, Evaluation) yang dikembangkan oleh Robert Maribe Branch. Teknik pengumpulan data menggunakam observasi, angket dan tes. Hasil penelitian ini menunjukkan bahwa: (1) hasil validasi LKPD memperoleh nilai 3,75 dengan kategori sangat valid, hasil validasi materi 3,78 dengan kategori sangat valid, validasi RPP memperoleh nilai 3,73 dengan kategori sangat valid, dan lembar tes hasil belajar memperoleh nilai 3,56 dengan kategori sangat valid; (2) hasil kepraktisan dari keterlaksanaan pembelajaran pertemuan I memperoleh persentase $75 \%$ dan pertemuan II memperoleh persentase $94 \%$ dengan kategori terlaksana baik, sedangkan aktivitas anak pertemuan I memperoleh persentase $77 \%$ dan pertemuan II memperoleh persentase $94 \%$ dengan kategori aktif dan hasil angket penilaian guru memperoleh rata-rata persentase 97\%; (3) hasil keefektifan dari lembar kerja peserta didik berbasis proyek yang dikembangkan memperoleh nilai n-gain 0,67 dengan kategori sedang. Kesimpulan dari lembar kerja peserta didik berbasis proyek yang dikembangkan pada materi siklus air valid, praktis, dan efektif dalam meningkatkan hasil belajar siswa kelas V sekolah dasar.
\end{abstract}

Kata Kunci: lembar kerja peserta didik, pembelajaran berbasis proyek, hasil belajar siswa

\begin{abstract}
This development research purpose to explain the validity, practicality and effectiveness of project-based student worksheets to improve the learning outcomes of fifth grade elementary school students. Development research uses the ADDIE (Analysis, Design, Development, Implementation, Evaluation) model developed by Robert Maribe Branch. Data collection techniques using observation, questionnaires and tests. The results of this study indicate that: (1) results of the validation of the student worksheets obtained a value of 3.75 with a very valid category, the results of material validation 3.78 with a very valid category, validation of the learning implementation plan obtained a value of 3.73 with a very valid category, and the learning outcomes test sheet obtained a score of 3.56 with a very valid category; (2) practical results of the results of the teacher's assessment questionnaire obtain an average percentage of 97\%; (3) results of the effectiveness of the developed project-based student worksheets obtained an n-gain value of 0.67 in the medium. The conclusion of the project-based student worksheet developed on the water cycle material is valid, practical, and effective in improving the learning outcomes of fifth grade elementary school students.
\end{abstract}

Keywords: student worksheet, project based learning, student learning result

Copyright (c) 2021 Arie Widya Murni, Fajar Nur Yasin

$\triangle$ Corresponding author :

Email : ariewidya.pgsd@unusida.ac.id

DOI $\quad:$ https://doi.org/10.31004/basicedu.v5i6.1696

ISSN 2580-3735 (Media Cetak)

ISSN 2580-1147 (Media Online)

Jurnal Basicedu Vol 5 No 6 Tahun 2021

p-ISSN 2580-3735 e-ISSN 2580-1147 
6197 Pengembangan Lembar Kerja Peserta Didik (LKPD) Berbasis Proyek pada Materi Siklus Air Kelas V Sekolah Dasar - Arie Widya Murni, Fajar Nur Yasin

DOI: https://doi.org/10.31004/basicedu.v5i6.1696

\section{PENDAHULUAN}

Menurut Sumaji (Awang, 2015) proses pembelajaran ilmu pengetahuan alam (IPA) di sekolah dasar (SD) hendaknya membuka kesempatan untuk memupuk rasa ingin tahu peserta didik dan memahami tentang alam secara sistematik. Hal ini akan membantu mereka mengembangkan kemampuan bertanya dan mencari jawaban atas fenomena alam. Sehingga pembelajaran IPA bukan hanya penguasaan tentang kumpulan pengetahuan yang berupa fakta, konsep, dan prinsip saja tetapi juga merupakan suatu proses penemuan. IPA menekankan pada pemberian pengalaman secara langsung kepada peserta didik, sehingga perlu LKPD yang lebih mengedepankan peserta didik sebagai pelaku utama dalam proses pembelajaran.

Pada dasarnya tujuan dari pembelajaran IPA itu sendiri yaitu menciptakan manusia yang berpengetahuan dan mengerti akan lingkungannya, tidak hanya paham secara teoritis tetapi paham akan temuannya sendiri di lingkungan mereka (Hairunisa et al., 2019). Tujuan dan ruang lingkup dari mata pelajaran IPA yang tercantum dalam Kurikulum 2013 tersebut sudah jelas bahwa IPA merupakan mata pelajaran yang erat kaitannya dengan lingkungan dan kehidupan sehari-hari (Susiloningsih, 2015). Namun kenyataanya implementasi pembelajaran IPA belum relevan dengan tujuan yang diharapkan, dan keterkaitan mata pelajaran IPA dengan lingkungan juga masih kurang. Permasalahan yangterjadi tersebut merupakan hasil nyata dari pembelajaran IPA yang masih belum berjalan dengan baik dan juga belum sesuai dengan apa yang diharapkan.

Berdasarkan hasil pengamatan di lapangan, ditemukan masalah mengenai hasil belajar IPA yang masih rendah. Hal tersebut terbukti dengan ditemukannya beberapa masalah, diantaranya adalah kegiatan pembelajaran mata pelajaran IPA kurang mengadakan kegiatan pengamatan dan percobaan-percobaan secara langsung terhadap materi yang diajarkan sehingga siswa terkesan hanya mendengarkan penjelasan guru dan menghafal buku teks (Hakim et al., 2020). Lembar Kegiatan Peserta Didik (LKPD) terpaku pada teks materi dan soal-soal, dan kurang mengembangkan kegiatan siswa yang berkaitan langsung dengan lingkungan siswa. Guru juga belum mempunyai susunan Lembar Kegiatan Peserta Didik (LKPD) yang sesuai dengan karakteristik mata pelajaran IPA dan karakteristik lingkungan belajar siswa, sehingga LKPD yang digunakan bisa lebih kontekstual. Guru kurang mengaitkan materi pembelajaran dengan kehidupan nyata, sehingga pengalaman belajar siswa belum terkonsep dalam kehidupan sehari-hari atau kehidupan nyata.

Pembelajaran IPA hendaknya berorientasi pada aktivitas-aktivitas yang mendukung terjadinya pemahaman konsep, prinsip, dan prosedur dalam kaitannya dengan konteks kehidupan mereka sehari-hari di dalam sekolah maupun luar sekolah (Aristiadi \& Putra, 2018). Dengan demikian pembelajaran IPA menjadi lebih menarik dan menyenangkan serta terciptanya pembelajaran yang aktif dan efektif. Untuk menciptakan pembelajaran IPA yang demikian, maka perlu dilakukan inovasi dalam hal startegi, pendekatan, dan bahan belajar. Dalam penelitian ini, inovasi yang akan dilakukan dalam rangka membuat pembelajaran IPA lebih menarik dan menyenangkan adalah dengan bahan belajar berupa Lembar Kerja Peserta Didik (LKPD).

Menurut Fahrie dalam Fannie \& Rohati (2014) Lembar Kegiatan Peserta Didik (LKPD) adalah lembaran yang digunakan sebagai pedoman di dalam pembelajaran serta berisi tugas yang harus dikerjakan oleh peserta didik. LKPD biasanya berupa petunjuk dan langkah- langkah untuk menyelesaikan suatu tugas. LKPD memuat kegiatan yang berisi tahapan- tahapan yang harus dikerjakan oleh peserta didik dalam menemukan konsep. LKPD merupakan salah satu bentuk bahan ajar yang sering digunakan oleh pendidik dalam menyampaikan topik pembelajaran. LKPD sendiri memuat materi maupun pertanyaan atau tugas untuk diselesaikan peserta didik. Dalam pembelajaran ilmu pengetahuan alam (IPA), adanya LKPD dapat membantu pendidik dalam menyampaikan topik pembelajaran mengenai IPA. Tetapi pada kenyataannya di sekolah belum mengembangkan LKPD yang menekan pada pengalaman langsung sehingga membuat peserta didik kurang aktif. 
6198 Pengembangan Lembar Kerja Peserta Didik (LKPD) Berbasis Proyek pada Materi Siklus Air Kelas V Sekolah Dasar - Arie Widya Murni, Fajar Nur Yasin

DOI: https://doi.org/10.31004/basicedu.v5i6.1696

Hal senada dijelaskan oleh Noprinda \& Soleh (2019) bahwa LKPD merupakan lembaran kertas yang berisikan kegiatan maupun soal-soal atau pertanyaan-pertanyaan yang harus dijawab oleh siswa pada saat melakukan aktivitas nyata dengan objek dan persoalan yang dipelajari. Adapun manfaat penggunaan LKPD dapat membantu guru untuk mengarahkan siswa agar mampu menemukan konsep-konsep baik dengan aktivitas sendiri atau berkelompok, dapat digunakan untuk mengembangkan keterampilan proses, sikap ilmiah, dan menumbuhkan minat siswa terkait dengan alam sekitarnya, serta dapat mempermudah guru untuk menilai keberhasilan siswa dalam mencapai sasaran pembelajaran (Kristyowati, 2018). Penggunaan LKPD dapat meningkatkan efisiensi dan efektivitas pembelajaran di sekolah, baik waktu, dana, fasilitas, maupun tenaga guna mencapai (Mukti et al., 2018).

LKPD dapat dikembangkan dengan adanya kreatifitas guru, seperti menciptakan buku yang berwarna dan dapat mengajak siswa berimajinasi. LKPD yang dapat digunakan dalam pembelajaran harus mengajak keaktifan siswa. Salah satunya dapat menggunakan LKPD berbasis proyek sehingga menimbulkan keaktifan siswa. Pembelajaran berbasis proyek dipilih karena mempunyai daya tarik tersendiri bagi siswa karena mampu mengajak siswa untuk aktif (Tasci, 2015). Kelebihan dari pembelajaran berbasis proyek adalah memberikan pengalaman khusus pada siswa karena melibatkan siswa. Hal ini akan membuat kesan tersendiri kepada siswa sehingga akan lebih mudah masuk ke dalam ingatan ketika belajar. Melalui LKPD, guru mendapat kesempatan untuk memancing siswa agar aktif dalam terlibat materi yang dibahas (Setyowati et al., 2018). LKPD juga dapat membuat proses pembelajaran lebih aktif. Dengan pembelajaran aktif, peserta didik mendapat pengalaman langsung sehingga tidak terbatas dengan pengetahuan belaka. Hal tersebut sesuai dengan konsep dari pembelajaran berbasis proyek.

Salah satu model pembelajaran yang dapat diterapkan dalam pembelajaran IPA yaitu model pembelajaran berbasis proyek. Model pembelajaran berbasis proyek ini merupakan salah satu model pembelajaran yang disarankan pada kurikulum 2013 yaitu bertujuan untuk mendorong kemampuan peserta didik dalam menghasilkan karya kontekstual, baik individu maupun kelompok. Model pembelajaran berbasis proyek (project based learning) adalah sebuah model pembelajaran inovatif yang menekankan belajar kontekstual melalui kegiatan-kegiatan yang kompleks. Pembelajaran berbasis proyek adalah cara yang konstruktif dalam pembelajaran yang menggunakan permasalahan sebagai stimulus dan berfokus pada aktivitas pelajar. pembelajaran berbasis proyek ini tidak hanya mengkaji hubungan antara informasi teoritis dan praktik, tetapi juga memotivasi perserta didik untuk merefleksi hal-hal yang perlu mereka pelajari dalam pembelajaran sebuah proyek nyata.

Pembelajaran yang dapat memfasilitasi siswa untuk berkarya baik secara individual maupun kelompok diantaranya adalah pembelajaran berbasis proyek dalam standar proses dinyatakan bahwa untuk mendorong kemampuan siswa menghasilkan karya konsektual, baik individual maupun kelompok maka sangat disarankan menggunakan model pembelajaran yang menghasilkan karya kontekstual, maka sangat disarankan menggunakan model pembelajaran yang menghasilkan karya nyata yaitu pembelajaran berbasis proyek. Menurut Amini, et al (2019) pembelajaran berbasis proyek didasarkan pada teori konstruktivisme dan merupakan pembelajaran siswa aktif (student centered learning), proses pembelajaran melalui pembelajaran berbasis proyek memungkinkan pendidik untuk memberikan pembelajaran pengalaman langsung siswa. Pembelajaran berbasis proyek memfokuskan pada aktivitas siswa yang berupa pengumpulan informasi dan pemanfaatanya untuk menghasilkan sesuatu yang bermanfaat bagi kehidupan siswa itu sendiri maupun bagi orang lain. Uno (2010) menyatakan bahwa suasana yang mestinya tercipta dalam proses pembelajaran adalah bagaimana siswa berperan aktif dalam belajar.

Permasalahan yang sering timbul selama ini yaitu pembelajaran berbasis proyek belum banyak diterapkan pada LKPD di sekolah-sekolah. Cara mengajar guru yang sering menggunakan gambar dan pemberian materi dengan metode ceramah membuat peserta didik cenderung kurang memahami materi yang disampaikan dan membuat peserta didik menjadi pasif dalam proses pembelajaran. Model pembelajaran 
tersebut belum dapat mendukung proses pembelajaran yang berlangsung, dalam penyampaian materi pada mata pelajaran IPA seharusnya perlu menggunakan model pembelajaran berbasis proyek yaitu dengan peserta didik terjun langsung dalam pembelajaran sehingga akan lebih mudah untuk mamahamkan peserta didik. Dengan demikian peserta didik dapat meningkatkan kreatifitas dan keaktifan sehingga peserta didik dapat membuat suatu produk dengan praktikum.

Temuan penelitian ini didukung dengan penelitian yang sudah ada sebelumnya. Muskania \& Wilujeng (2017) dalam penelitiannya menyatakan perangkat pembelajaran IPA berbasis project based learning yang dikembangkan layak digunakan dengan kriteria baik sekali sesuai dengan hasil validasi serta uji coba dan hasil uji independent sampel $t$-test menunjukkan bahwa perangkat pembelajaran berbasis project based learning memberikan pengaruh signifikan terhadap scientific literacy peserta didik. Krismawati (2019) dalam penelitiannya juga menyatakan bahan ajar penulisan sejarah berbasis project based learning memberikan pengaruh positif terhadap peningkatan prestasi siswa, hal ini ditunjukkan dengan kenaikan nilai pretest dan posttest dari kelas eksperimen adalah sebesar 0.53 dengan kategori sedang, sedangkan kelas kontrol sebesar 0.36 dengan kategori sedang

Berdasarkan latar belakang masalah di atas, salah satu bahan ajar yang sesuai yang dapat dijadikan alat bantu pembelajaran IPA adalah penggunaan sumber belajar dalam bentuk LKPD yang lebih inovatif. Peserta didik akan sulit memahami materi siklus air jika hanya menggunakan metode ceramah yang berpusat pada guru. Oleh karena itu peneliti mengajukan penelitian dengan mengambil judul "Pengembangan Lembar Kerja Peserta Didik (LKPD) Berbasis Proyek pada Materi Siklus Air Kelas V Sekolah Dasar”.

\section{METODE PENELITIAN}

Borg \& Gall (1983) mendefinisikan bahwa penelitian pengembangan sebagai proses yang digunakan untuk mengembangkan dan memvalidasi produk pendidikan. Langkah-langkah dari proses ini biasanya disebut sebagai siklus research and development (R \& D) yang mempelajari temuan penelitian yang berkaitan dengan produk yang dikembangkan, mengembangkan produk berdasarkan temuan ini, bidang pengujian dalam pengaturan dimana akan digunakan akhirnya dan merevisinya untuk memperbaiki kekurangan yang ditemukan dalam tahap mengajukan pengujian. Rancangan penelitian ini menggunakan rancangan penelitian dan pengembangan model ADDIE (Analysis, Design, Development, Implementation, Evaluation) yang dikembangkan oleh Robert Maribe Branch. Model pengembangan ADDIE dipiloh karena efektif, dinamis dan mendukung kinerja program itu sendiri.

Hal ini senada dengan pendapat Astutik \& Prahani (2018) bahwa penelitian pengembangan digunakan untuk produk dan mendapatkan efektivitas produk. Instrumen dan prosedur yang digunakan dalam penelitian ini adalah 1) Lembar validasi sebagai penilaian yang diberikan oleh validator dengan memberikan tanda centang $(\sqrt{ })$; 2) Lembar observasi keterlaksanaan pembelajaran dan aktivitas siswa digunakan untuk memperoleh data kepraktisan lembar kerja peserta didik dalam menunjang kegiatan pembelajaran. Lembar angket diberikan kepada guru untuk memperikan penilaian produk yang dikembangkan; 3) Lembar tes hasil belajar digunakan untuk memperoleh data keefektifan penggunaan lembar kerja peserta didik (LKPD) berbasis proyek pada materi siklus air siswa kelas V sekolah dasar.perkembangan kognitif dan kecerdasan sosial emosional anak.

Penelitian dilaksanakan di SDN Randegan, Kecamatan Tanggulangin Kabupaten Sidoarjo. Subjek dalam uji coba ini berjumlah 30 siswa kelas 5A SDN Randegan Sidoarjo sebagai kelas eksperimen dan 30 siswa kelas 5B SDN Randegan Sidoarjo sebagai kelas kontrol.

Penelitian ini termasuk dalam penelitian pengembangan (research and development). Melalui penelitian dan pengembangan ini, peneliti berusaha mengembangkan perangkat pembelajaran yang berupa Lembar Kegiatan Peserta Didik (LKPD) Pembelajaran berbasis proyek. Prosedur pengembangan menggunakan desain 
pembelajaran model ADDIE, namun yang digunakan peneliti hanya tiga tahapan yaitu tahap analisis (Analysis), tahap desain (Design),dan tahap pengembangan (Development). Tujuan utama penelitian ini yaitu mengembangkan lembar kegiatan peserta didik (LKPD) pembelajaran berbasis proyek. Berikut ini adalah bagan alur penelitian pengembangan model ADDIE:

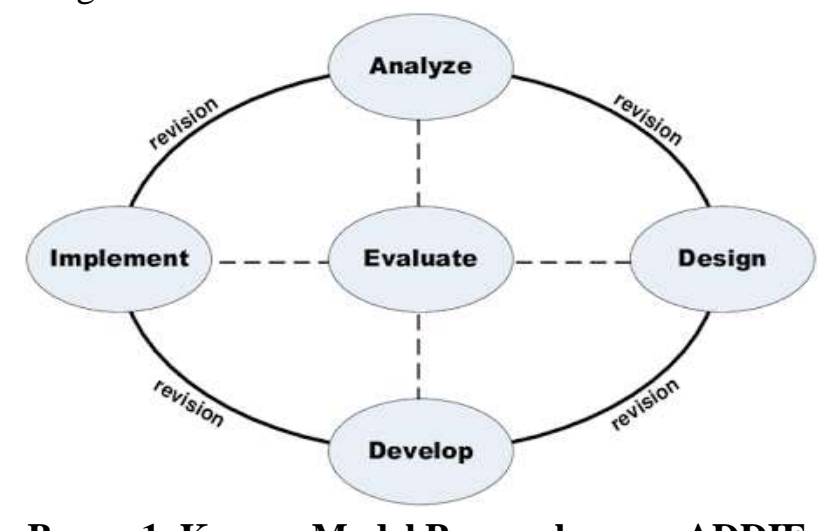

Bagan 1. Konsep Model Pengembangan ADDIE

(Branch, 2010)

Langkah pertama yaitu tahap analyze (analisis). Tahap analisis adalah suatu tahap pengumpulan informasi yang dapat dijadikan bahan untuk membuat produk, dalam hal ini produk yang dihasilkan adalah LKPD. Pengumpulan informasi ini berupa analisis kebutuhan, analisis karakteristik peserta didik, dan analisis kurikulum 2013. Langkah kedua adalah tahap design (desain). Pada tahap desain, LKPD dirancang untuk mempermudah peneliti dalam merancang LKPD. Tahap perancangan produk berupa LKPD yaitu rencana pelaksanaan pembelajaran (RPP), perumusan indikator, tujuan pembelajaran dan pembuatan draf LKPD materi siklus air. Langkah ketiga yaitu tahap develop (pengembangan). Pengembangan adalah tahap proses mengembangkan sesuatu yang telah dibuat dalam tahap desain agar menjadi sebuah produk. Hasil akhir dari tahap ini adalah sebuah produk yang akan diujicobakan.

Langkah keempat adalah tahap implement (implementasi). Pada tahap ini rancangan dan Lembar kerja peserta didik berbasis problem based learning yang telah dikembangkan diimplementasikan pada situasi yang nyata yaitu di kelas (proses pembelajaran). Selama implementasi, rancangan permainan yang telah dikembangkan diterapkan pada kondisi yang sebenarnya. Setelah penerapan di lapangan kemudian dilakukan evaluasi awal untuk memberi umpan balik pada penerapan model berikutnya. Tahap implementasi dilakukan pada peserta didik di SDN Randegan Kecamatan Tanggulangin Kabupaten Sidoarjo. Selama uji coba berlangsung, peneliti membuat catatan tentang kekurangan dan kendala yang masih terjadi ketika produk tersebut diimplementasikan. Langkah terakhir melakukan evaluate (evaluasi). Evaluasi adalah proses untuk menganalisis penggunaan lembar kerja peserta didik berbasis problem based learning yang telah dikembangkan pada tahap implementasi masih terdapat kekurangan dan kelemahan atau tidak. Saran dan masukan dari validator ahli juga dijadikan acuan dan pertimbangan oleh peneliti. Apabila sudah tidak terdapat revisi lagi, maka pruduk layak digunakan.

Data pengembangan produk diperolah dari lembar kerja peserta didik (LKPD) berbasis proyek yang telah divalidasi oleh pakar/ahli media dan ahli materi. Hasil penilaian tersebut disimpulkan dalam bentuk deskriptif kualitatif menggunakan acuan likert. Tabel acuan likert adalah sebagai berikut.

Tabel 1. Skala Penilaian Validasi

\begin{tabular}{cc}
\hline Skor & Kriteria \\
\hline 1 & Tidak baik \\
\hline 2 & kurang baik \\
\hline 3 & Cukup baik \\
\hline
\end{tabular}


6201 Pengembangan Lembar Kerja Peserta Didik (LKPD) Berbasis Proyek pada Materi Siklus Air Kelas V Sekolah Dasar - Arie Widya Murni, Fajar Nur Yasin

DOI: https://doi.org/10.31004/basicedu.v5i6.1696

\begin{tabular}{cc}
\hline 4 & Baik \\
\hline 5 & Sangat baik \\
\hline
\end{tabular}

(Sugiyono, 2012)

Data yang dihasilkan dari validasi berupa skor. Persentase kesesuaian pendapat antar validator dihitung menggunakan percentage of agreement $(R)$, dengan rumus:

$$
R=\frac{\sum K}{\sum N}
$$

Keterangan:

$\mathrm{R}$ = Rata-rata

$\mathrm{K}$ = Jumlah aspek yang dinilai

$\mathrm{N}$ = Jumlah keseluruhan aspek

Hasil analisis data pada setiap aspek skor rata-rata kemudian diinterpretasikan ke dalam tabel 2 berikut

Tabel 2. Klasifikasi Koefisien Validitas

\begin{tabular}{ccc}
\hline Interval Nilai & Kategori Nilai & Keterangan \\
\hline $3,6 \leq \mathrm{P} \leq 4,0$ & Sangat Valid & Dapat digunakan Tanpa Revisi \\
\hline $2,6 \leq \mathrm{P} \leq 3,5$ & Valid & Dapat digunakan dengan revisi kecil \\
\hline $1,6 \leq \mathrm{P} \leq 2,5$ & Kurang Valid & Dapat digunakan dengan revisi besar \\
\hline $1,0 \leq \mathrm{P} \leq 1,5$ & Tidak Valid & Belum dapat digunakan \\
\hline Ratumanan, 2015$)$ & &
\end{tabular}

Data hasil observasi didapatkan dari pengamatan aktivitas guru dan siswa selama pelaksanaan pembelajaran daring dengan menggunakan zoom. Hasil observasi berupa skor dengan menggunakan acuan likert. Tabel acuan likert adalah sebagai berikut.

Tabel 3. Skala Penilaian Observasi

\begin{tabular}{cc}
\hline Skor & Kriteria \\
\hline 1 & Tidak baik \\
2 & Kurang baik \\
3 & Cukup baik \\
4 & Baik \\
5 & Sangat baik \\
\hline
\end{tabular}

(Sugiyono, 2012)

Skor yang didapatkan dari hasil observasi, kemudian diolah dengan menggunakan rumus berikut.

(Riduwan, 2013)

$$
p \%=\frac{\text { jumlah skor hasil pengumpulan data }}{\text { skor maksimal }} \times 100 \%
$$

Persentase observasi digunakan untuk mengetahui pelaksanaan proses pembelajaran saat menggunakan lembar kerja peserta didik (LKPD) berbasis proyek. Setelah hasil persentase didapatkan kemudian diinterpretasikan berdasarkan tabel kriteria berikut. 
6202 Pengembangan Lembar Kerja Peserta Didik (LKPD) Berbasis Proyek pada Materi Siklus Air Kelas V Sekolah Dasar - Arie Widya Murni, Fajar Nur Yasin

DOI: https://doi.org/10.31004/basicedu.v5i6.1696

Tabel 4. Kriteria Persentase Observasi

\begin{tabular}{ccc}
\hline No. & Skor Rata-rata & Kategori \\
\hline 1. & $0 \%-20 \%$ & Sangat Kurang \\
\hline 2. & $21 \%-40 \%$ & Kurang \\
\hline 3. & $41 \%-70 \%$ & Cukup \\
\hline 4. & $71 \%-80 \%$ & Baik / Layak \\
\hline 5. & $81 \%-100 \%$ & Sangat Baik / Sangat Layak \\
\hline
\end{tabular}

(Riduwan, 2013)

Data hasil kuesioner didapatkan dengan melalui angket dari penilaian guru terhadap lembar kerja peserta didik (LKPD) berbasis proyek yang dikembangkan. Skala pengukuran data kuesioner menggunakan acuan skala Guttman. Skala Guttman digambarkan dalam tabel berikut

Tabel 5. Skala Penilaian Angket Siswa

\begin{tabular}{cc}
\hline Jawaban & Skor \\
\hline Ya & 1 \\
\hline Tidak & 0 \\
\hline
\end{tabular}

(Riduwan, 2013)

Skor yang didapatkan dari hasil angket penilaian guru, kemudian diolah dengan menggunakan rumus berikut.

$$
p \%=\frac{\text { jumlah skor hasil pengumpulan data }}{\text { skor maksimal }} \times 100 \%
$$

(Riduwan, 2013)

Persentase angket digunakan untuk mengetahui penilaian guru terhadap lembar kerja peserta didik (LKPD) berbasis proyek pada materi siklus air siswa kelas V sekolah dasar. Setelah hasil persentase didapatkan kemudian diintrepretasikan berdasarkan tabel kriteria berikut.

Tabel 6. Kriteria Persentase Angket Siswa

\begin{tabular}{ccc}
\hline No. & Skor Rata-rata & Kategori \\
\hline 1. & $0 \%-20 \%$ & Sangat Kurang \\
\hline 2. & $21 \%-40 \%$ & Kurang \\
\hline 3. & $41 \%-70 \%$ & Cukup \\
\hline 4. & $71 \%-80 \%$ & Baik / Layak \\
\hline 5. & $81 \%-100 \%$ & Sangat Baik / Sangat Layak \\
\hline Riduwan, 2013) & &
\end{tabular}

Analisis data tes hasil belajar pada siswa kelas V sekolah dasar dianalisis menggunakan gain score pada nilai pretest dan posttest. Besar peningkatan dianalisis dengan menggunakan rumus n-gain (Hake, 1999)

$$
<\mathrm{g}>=\frac{\text { skor posttest }- \text { pretest }}{\text { skor maksimum }- \text { pretest }}
$$

Skor gain yang diperoleh diinterpretasikan ke dalam kategori n-gain di bawah ini. 
6203 Pengembangan Lembar Kerja Peserta Didik(LKPD) Berbasis Proyek pada Materi Siklus Air Kelas V Sekolah Dasar - Arie Widya Murni, Fajar Nur Yasin

DOI: https://doi.org/10.31004/basicedu.v5i6.1696

Tabel 7. Klasifikasi N-Gain Score

\begin{tabular}{cc}
\hline Nilai Gain Ternormalisasi & Interpretasi \\
\hline$-1,00 \leq \mathrm{g}<0,00$ & Terjadi penurunan \\
\hline $\mathrm{g}=0,00$ & Tidak terjadi peningkatan \\
\hline $0,00<\mathrm{g}<0,30$ & Rendah \\
\hline $0,30 \leq \mathrm{g}<0,70$ & Sedang \\
\hline $0,70 \leq \mathrm{g} \leq 1,00$ & Tinggi \\
\hline
\end{tabular}

Penelitian pengembangan lembar kerja peserta didik (LKPD) berbasis proyek pada materi siklus air siswa kelas V Sekolah Dasar berupa kuantitatif dengan menggunakan desain pretest - posttest control group design. Pola desain pretest - posttest control group design. design digambarkan sebagai berikut.

Tabel 8. Skema Model Pretest-Posttest Control Group Desain

\begin{tabular}{cccc}
\hline $\mathrm{E}$ & $\mathrm{O} 1$ & $\mathrm{X}$ & $\mathrm{O} 2$ \\
\hline $\mathrm{K}$ & $\mathrm{O} 3$ & - & $\mathrm{O} 4$ \\
\hline
\end{tabular}

Keterangan:

$\mathrm{E}=$ Kelas Eksperimen

$\mathrm{K}=$ Kelas Kontrol

$\mathrm{X}=$ Perlakuan lembar kerja peserta didik berbasis proyek

- $\quad$ = Perlakuan buku siswa

$\mathrm{O} 1=$ Hasil pretest kelas eksperimen

$\mathrm{O} 2=$ Hasil posttest kelas eksperimen

$\mathrm{O} 3=$ Hasil pretest kelas kontrol

$\mathrm{O} 4$ = Hasil posttest kelas kontrol

(Sugiyono, 2012)

Analisis data dalam penelitian ini menggunakan rumus independent $t$-test untuk mengetahui keefektifan dari lembar kerja peserta didik (LKPD) berbasis proyek yang dikembangkan. Analisis statistik termasuk uji statistik parametrik maka harus memenuhi uji prasyarat yaitu uji normalitas dan uji homogenitas. Tingkat kesalahan (taraf signifikansi) yang digunakan dalam penelitian ini sebesar 0.05. Uji prasyarat analisis ini bertujuan untuk mengetahui ada penyimpangan atau tidaknya terhadap variabel-variabel yang ada. Setelah dilakukan uji prasyarat, selanjutnya dilakukan analisis uji t independent sampel t-test menggunakan SPSS.

\section{HASIL DAN PEMBAHASAN}

\section{Kevalidan Lembar Kerja Peserta Didik (LKPD) Berbasis Proyek}

Sebelum digunakan untuk penelitian, instrumen yang digunakan divalidasi terlebih dahulu oleh validator ahli. Keseluruhan instrumen yang divalidasi adalah validasi lembar kerja peserta didik (LKPD) berbasis proyek yang dikembang, validasi materi, validasi RPP, validasi lembar tes hasil belajar. Adapun hasil validasi oleh validator disajikan dalam di bawah ini.

Tabel 9. Hasil Validasi Instrumen Penelitian oleh Ahli

\begin{tabular}{llll}
\hline No. & Instrumen yang divalidiasi & Skor Rata-Rata & Predikat \\
\hline 1. & Lembar kerja peserta didik (LKPD) berbasis proyek & 3,75 & Sangat valid \\
\hline 2. & Materi & 3,78 & Sangat valid \\
\hline 3. & Rencana pelaksanaan pembelajaran & 3,73 & Sangat valid \\
\hline 4. & Lembar tes hasil belajar & 3,56 & Sangat valid \\
\hline
\end{tabular}


6204 Pengembangan Lembar Kerja Peserta Didik(LKPD) Berbasis Proyek pada Materi Siklus Air Kelas V Sekolah Dasar - Arie Widya Murni, Fajar Nur Yasin

DOI: https://doi.org/10.31004/basicedu.v5i6.1696

Dari hasil validasi dapat dilihat bahwa keseluruhan instrumen yang digunakan untuk penelitian memperoleh kategori sangat valid karena berada pada rentang nilai 3,6-4,0. Kevalidan terhadap lembar kerja peserta didik (LKPD) berbasis proyek yang dikembangkan dilakukan untuk mengetahui tingkat kelayakan dari suatu produk yang dikembangkan.

Ukuran sebuah produk dapat dikatakan berkualitas jika telah memenuhi beberapa aspek kualitas produk. Produk yang dikembangkan dalam penelitian pengembangan ini berdasarkan penilaian validator ahli telah menunjukkan bahwa semua aspek yang diuji memiliki skor kevalidan produk Sangat Baik (SB). Pernyataan tersebut sesuai dengan pendapat yang dikemukakan Nieveen (1999) bahwa suatu produk dapat dikatakan berkualitas apabila memenuhi aspek-aspek kualitas produk antara lain (1) kevalidan (validity); (2) kepraktisan (practicy); (3) keefektifan (effectiveness).

\section{Kepraktisan Lembar Kerja Peserta Didik (LKPD) Berbasis Proyek}

Penilaian kepraktisan produk meliputi keterlaksanaan pembelajaran, aktivitas siswa dan penilaian guru terhadap lembar kerja peserta didik (LKPD) berbasis proyek yang telah dikembangkan. Dalam kondisi pandemi Covid-19 ini kegiatan pembelajaran tatap muka di sekolah belum bisa dilaksanakan, sehingga kegiatan pembelajaran dilakukan secara daring melalui aplikasi zoom dan google classroom. Berikut hasil keterlaksanaan pembelajaran dan aktivitas siswa yang berasal dari penilaian pengamat dinyatakan sebagai berikut.

Tabel 10. Hasil Rekapitulasi Kepraktisan

\begin{tabular}{llclll}
\hline No. & Aspek yang dinilai & Pelaksanaan & Rata-Rata & Persentase & Keterangan \\
\hline 1 & $\begin{array}{l}\text { Keterlaksanaan } \\
\text { pembelajaran }\end{array}$ & Pretest & 3,00 & $75 \%$ & $\begin{array}{l}\text { Terlaksanan } \\
\text { sangat baik }\end{array}$ \\
2 & $\begin{array}{l}\text { Keterlaksanaan } \\
\text { pembelajaran }\end{array}$ & Posttest & 3,77 & $94 \%$ & $\begin{array}{l}\text { Terlaksanan } \\
\text { sangat baik }\end{array}$ \\
3 & Aktivitas siswa & Pretest & 3,1 & $77 \%$ & Aktif \\
4 & Aktivitas siswa & Posttest & 3,8 & $94 \%$ & Aktif \\
\hline
\end{tabular}

Kegiatan pembelajaran pertemuan I (pretest), tahap keterlaksanaan memperoleh nilai dari kedua pengamat secara keseluruhan memperoleh persentase $75 \%$ dengan kategori terlaksana sangat baik, sedangkan pada pertemuan II (posttest) memperoleh persentase 94\% dengan kategori sangat baik. Hasil observasi aktivitas anak pada pertemuan I mendapatkan nilai dari dua pengamat secara keseluruhan memperoleh persentase $77 \%$ dengan kategori aktif, sedangkan aktivitas anak pada pertemuan II mendapatkan nilai persentase $94 \%$ dengan kategori aktif.

Produk dapat dikatakan praktis apabila memudahkan pengguna untuk memakai atau menggunakan produk. Produk yang dihasilkan dalam penelitian pengembangan ini dilakukan uji coba untuk mengetahui tingkat kepraktisan sebuah produk. Hasil uji coba dapat diketahui dari hasil observasi 2 pengamat. Pembelajaran IPA hendaknya berorientasi pada aktivitas-aktivitas yang mendukung terjadinya pemahaman konsep, prinsip, dan prosedur dalam kaitannya dengan konteks kehidupan mereka sehari-hari di dalam sekolah maupun luar sekolah (Aristiadi \& Putra, 2018). Dengan demikian pembelajaran IPA menjadi lebih menarik dan menyenangkan serta terciptanya pembelajaran yang aktif dan efektif. Untuk menciptakan pembelajaran IPA yang demikian, maka perlu dilakukan inovasi dalam hal startegi, pendekatan, dan bahan belajar. Dalam penelitian ini, inovasi yang akan dilakukan dalam rangka membuat pembelajaran IPA lebih menarik dan menyenangkan adalah dengan bahan belajar berupa Lembar Kerja Peserta Didik (LKPD).

Selanjutnya, hasil angket respon penilaian guru terhadap lembar kerja peserta didik yang dikembangkan. Hasil angket ini diisi oleh 2 guru kelas V SD. Berdasarkan hasil penilaian guru terhadap lembar kerja peserta didik (LKPD) berbasis proyek dengan rata-rata persentase 97\%. Hal ini berarti lembar 
6205 Pengembangan Lembar Kerja Peserta Didik (LKPD) Berbasis Proyek pada Materi Siklus Air Kelas V Sekolah Dasar - Arie Widya Murni, Fajar Nur Yasin

DOI: https://doi.org/10.31004/basicedu.v5i6.1696

kerja peserta didik (LKPD) berbasis proyek pada materi siklus air kelas V sekolah dasar dapat dikatakan sangat praktis.

Menurut Nieveen (1999) selain harus valid, perangkat pembelajaran (RPP) juga harus praktis dan efektif. Tidak hanya RPP, lembar kerja peserta didik harus layak sebelum diuji cobakan. Lebih lanjut, Sardiman (2014) berpendapat bahwa dalam belajar itu perlu ada aktivitas, sebab pada prinsipnya belajar itu adalah berbuat atau learning by doing. Aktivitas merupakan prinsip atau asas yang sangat penting dalam interaksi belajar. Menurut Nur \& Wikandari (2000) belajar lebih dari sekadar mengingat. Seorang anak benarbenar mengerti dan dapat menerapkan ilmu pengetahuan, mereka harus bekerja keras untuk memecahkan masalah, menemukan sesuatu dan selalu berhubungan dengan ide atau gagasan. Proses pembelajaran yang diharapkan terjadi menurut Aunurrahman (2009) adalah suatu proses yang dapat mengembangkan potensipotensi anak secara menyeluruh dan terpadu. Untuk itulah, dalam proses pembelajaran guru tidak hanya dituntut menyampaikan materi pelajaran, tetapi harus mampu mengaktualisasi peran strategisnya dalam upaya membentuk watak anak melalui pengembangan kepribadian dan nilai-nilai yang berlaku.

\section{Keefektifan Lembar Kerja Peserta Didik (LKPD) Berbasis Proyek}

Keefektifan lembar kerja peserta didik (LKPD) berbasis proyek yang dikembangkan peneliti dapat dilihat dari hasil tes yang diberikan yaitu tes awal (pretest) dan tes akhir (posttest). Desain pada penelitian dan pengembangan ini menggunakan pretest-posttest control group design. Pada kelas ekspermen diberikan treatment lembar kerja peserta didik (LKPD) berbasis proyek, sedangkan pada kelas kontrol dengan pembelajaran konvensional yang biasa dilakukan guru.

Keefektifan produk dapat dilihat dari hasil peningkatan kemampuan anak dari sebelum diberikan treatment (pretest) dan sesudah diberikan treatment (posttest). Hal tersebut sesuai dengan pernyataan Purwanto (2011) yang menyatakan bahwa hasil belajar digunakan untuk mengetahui seberapa jauh seseorang menerima atau memahami bahan atau materi yang telah disampaikan. Pada penelitian dan pengembangan ini keefektifan dilihat dari tes hasil belajar.

Tabel 11. Rekapitulasi Nilai Hasil Belajar Siswa

\begin{tabular}{clcc}
\hline \multirow{2}{*}{ No. } & \multicolumn{1}{c}{ Deskripsi } & \multicolumn{2}{c}{ Skor Maksimal = 100 } \\
\cline { 3 - 4 } & & Pretest & Posttest \\
\hline 1. & Rata-Rata & 74 & 90,8 \\
\hline 2. & N-Gain & & 0,67 \\
\hline 3. & Nilai Tertinggi & 85 & 100 \\
\hline 4. & Nilai Terendah & 55 & 55 \\
\hline
\end{tabular}

Analisis data menggunakan uji beda independent $t$-test untuk menjawab rumusan masalah dan tujuan dalam penelitian mengenai efektivitas lembar kerja peserta didik (LKPD) berbasis proyek yang dikembangkan, dimana analisis statistik termasuk uji statistik parametrik maka wajib memenuhi uji prasyarat yaitu uji normalitas dan uji homogenitas. Tingkat kesalahan (taraf signifikansi) yang digunakan dalam penelitian ini sebesar 0.05. Tujuan dari uji prasyarat analisis ini untuk mengetahui ada tidaknya penyimpangan terhadap variabel-variabel yang ada. Uji prasyarat yang digunakan yaitu sebagai berikut.

Guna mengetahui normal tidaknya data dapat dilihat dari besarnya nilai p uji chi-kuadrat setiap variabel yang akan diteliti. Apabila nilai $\mathrm{p} \geq 0.05$ maka data berdistribusi normal. Sebaliknya apabila nilai $\mathrm{p}<0.05$ maka data tidak berdistribusi normal. Hasil uji normalitas dari beberapa variabel dalam penelitian ini bisa dilihat dari tabel berikut. 

Sekolah Dasar - Arie Widya Murni, Fajar Nur Yasin

DOI: https://doi.org/10.31004/basicedu.v5i6.1696

Tabel 12. Hasil Uji Normalitas

\begin{tabular}{clcc}
\hline Kelompok & \multicolumn{1}{c}{ Variabel } & $\begin{array}{c}\text { Signifikansi } \\
(\mathbf{p})\end{array}$ & Keterangan \\
& Hasil belajar pretest & 0.299 & Normal \\
Kontrol & Hasil belajar posttest & 0.180 & Normal \\
\hline \multirow{2}{*}{ Eksperimen } & Hasil belajar pretest & 0.180 & Normal \\
& Hasil belajar posttest & 0.392 & Normal \\
\hline
\end{tabular}

Berdasarkan tabel di atas,, dapat dilihat bahwa nilai signifikansi untuk variabel hasil belajar pretest dan posttest pada kelompok kontrol dan eksperimen lebih besar dari 0.05 , sehingga data penelitian dinyatakan berdistribusi normal.

Uji homogenitas dapat dilakukan dengan menggunakan Levene's tes, dengan melihat taraf signifikansi dari nilai Levene hitung. Jika nilai Levene menunjukkan taraf signifikansi lebih dari 0.05 maka dapat dikatakan tidak ada perbedaan varian antar kelompok sampel atau dengan kata lain varian antar kelompok adalah sama. Hasil uji homogenitas dapat dilihat pada tabel berikut.

Tabel 13. Hasil Uji Homogenitas

\begin{tabular}{|c|c|c|c|}
\hline & Kelas & Signifikansi & Keterangan \\
\hline \multirow{2}{*}{ Pretest } & Kontrol & \multirow{2}{*}{0,387} & \multirow{2}{*}{ Homogen } \\
\hline & Eksperimen & & \\
\hline \multirow{2}{*}{ Posttest } & Kontrol & \multirow{2}{*}{0,671} & \multirow{2}{*}{ Homogen } \\
\hline & Eksperimen & & \\
\hline
\end{tabular}

Berdasarkan tabel di atas, uji homogenitas pada pretest memperoleh nilai sebesar 0.387 yang berarti lebih besar dari 0.05 , sedangkan uji homogenitas posttest menunjukkan nilai 0,671 berarti lebih besar dari 0,05. Dari kedua data tersebut, maka dapat dikatakan tidak ada perbedaan varian antar kelompok sampelatau dengan kata lain varian antar kelompok variabel pre test dan post test hasil belajar adalah sama atau homogen.

Persyaratan uji statistik parametrik yang terdiri dari uji normalitas dan uji homogenitas telah memenuhi, sehingga bisa dilaksanakan tahap analisis selanjutnya. Prasyarat analisis sudah dilakukan, tahap selanjutnya yaitu melakukan analisis data. Teknik analisis data menggunakan uji independen $t$ test. Oleh karena pada variabel hasil belajar memenuhi asumsi normalitas maka digunakan uji independent $t$ test yang akan digunakan untuk menguji hipotesis penelitian yang berbunyi "Terdapat perbedaan hasil belajar dengan menggunakan lembar kerja peserta didik (LKPD) berbasis proyek pada materi siklus air siswa kelas $\mathrm{V}$ sekolah dasar".

Tabel 14. Hasil Pengujian Hipotesis

\begin{tabular}{|c|c|c|c|}
\hline & t hitung & Sig. (p) & Keterangan \\
\hline Pretest & 1,468 & 0,147 & Tidak ada beda hasil belajar \\
\hline Posttest & 3,665 & 0,001 & Ada beda hasil belajar \\
\hline
\end{tabular}

Berdasarkan tabel 12 di atas, penghitungan memakai uji signifikansi pada nilai pretest penelitian ini diperoleh $t_{h i t u n g}$ sebesar 1,468 dengan signifikan sebesar 0.147. Jadi, dapat diambil kesimpulan nilai signifikansi (p) > 0,05 maka $\mathrm{H}_{\mathrm{a}}$ ditolak, sehingga saat pretest dapat disimpulkan bahwa tidak terdapat perbedaan yang signifikan sebelum menggunakan lembar kerja peserta didik (LKPD) berbasis proyek pada materi siklus air siswa kelas V sekolah dasar. Sedangkan berdasarkan tabel nilai posttest pada penelitian ini diperoleh nilai signifikansi $(\mathrm{p})<0.05$, maka kesimpulannya $\mathrm{H}_{\mathrm{a}}$ diterima, sehingga dapat disimpulkan bahwa 
6207 Pengembangan Lembar Kerja Peserta Didik (LKPD) Berbasis Proyek pada Materi Siklus Air Kelas V Sekolah Dasar - Arie Widya Murni, Fajar Nur Yasin

DOI: https://doi.org/10.31004/basicedu.v5i6.1696

setelah dilakukan treatment berupa lembar kerja peserta didik (LKPD) berbasis proyek terdapat perbedaan hasil belajar siswa pada materi siklus air V sekolah dasar.

Hasil penghitungan menunjukkan nilai rata-rata posttest hasil belajar pada kelas kontrol sebesar 74 , sedangkan nilai rata-rata posttest hasil belajar pada kelas eksperimen sebesar 90.8. Berdasarkan nilai rata- rata tersebut, dapat dikatakan ada perbedaan hasil belajar antara kelompok kontrol dan eksperimen. Hal ini diperkuat dengan hasil uji $t$ test yaitu nilai $t_{\text {hitung }}=3,665$ dengan tingkat signifikan (p) sebesar 0.001 , berarti kurang dari 0,05. Sehingga terbukti bahwa terdapat perbedaan hasil belajar dengan menggunakan lembar kerja peserta didik (LKPD) berbasis proyek pada materi siklus air siswa kelas V sekolah dasar. Dengan kata lain, penerapan lembar kerja peserta didik (LKPD) berbasis proyek pada materi siklus air yang dikembangkan untuk siswa kelas V sekolah dasar efektif.

Salah satu teori yang berkembang pada saat ini adalah Teori behaviorisme yang berpendapat bahwa Peserta Didik akan menjadi lebih aktif dan mencapai tujuan belajar yang diharapkan jika diberi ransangan. Konsep dan gambar atau ilustrasi yang terdapat pada LKPD berbasis proyek ini, diharapkan dapat merangsang dan mengembangkan imajinasi para Peserta Didik untuk berfikir, menjabarkan konsep dan mengemukan pendapat sesuai dengan materi yang terdapat pada LKPD berbasis proyek. Teori belajar yang kedua adalah teori belajar kognitif. LKPD berbasis proyek yang dikembangkan ini dapat memicu perkembangan peserta didik, konsep dan pertanyaan yang terdapat pada LKPD berbasis proyek ini merupakan materi yang harus dicari jawabannya. Proses menjabarkan konsep akan meningkatkan kemampuan kognitif para peserta didik. Selain itu, menurut Rofiah (2014) LKPD juga merupakan media pembelajaran karena dapat digunakan secara bersama dengan sumber belajar atau media pembelajaran yang lain. LKPD sebagai panduan bagi siswa untuk mengerjakan pekerjaan tertentu yang dapat meningkatkan dan memperkuat hasil belajar.

Pembelajaran yang dapat memfasilitasi siswa untuk berkarya baik secara individual maupun kelompok diantaranya adalah pembelajaran berbasis Proyek dalam standar proses dinyatakan bahwa untuk mendorong kemampuan siswa menghasilkan karya konsektual, baik individual maupun kelompok maka sangat disarankan menggunakan model pembelajaran yang menghasilkan karya kontekstual, maka sangat disarankan menggunakan model pembelajaran yang menghasilkan karya nyata yaitu model pembelajaran berbasis proyek (Sari et al., 2020). Pembelajaran berbasis proyek memfokuskan pada aktivitas siswa yang berupa pengumpulan informasi dan pemanfaatanya untuk menghasilkan sesuatu yang bermanfaat bagi kehidupan siswa itu sendiri maupun bagi orang lain, namun tetap terkait dengan komptensi dasar dan indikator yang dikembangkan.

Pembelajaran pada LKPD berbasis proyek harus dipadukan secara tepat. Untuk itulah, penelitian ini dilengkapi dengan Rencana Pelaksanaan pembelajaran. RPP ini terdapat didalam produk LKPD yang dikembangkan. Selain RPP juga dilengkapi dengan ringkasan bahan ajar sebagai pedoman Pendidik dalam memberikan materi pembelajaran harus berfokus pada pengetahuan dan keahlian intelektual, domain afektif terkait dengan sikap, motivasi, kesediaan berpartisipasi, menghargai apa yang sedang dipelajari dan pada akhirnya menghayati nilai nilai itu ke dalam kehidupan sehari-hari, sedangkan domain keterampilan berfokus pada menjalankan kegiatan motorik hingga satu tingkat akurasi, kelancaran, kecepatan, atau kekuatan tertentu (Eggen \& Kauchak, 2021).

Temuan dalam penelitian ini relevan dengan penelitian yang dilakukan oleh Zulkurnia, et al (2017) bahwa hasil belajar siswa pada uji coba produk meningkat, hal ini dibuktikan dengan hasil analisis uji thitung lebih besar dari t tabel sehingga pembelajaran dengan menggunakan LKPD dinyatakan efektif. Penelitian relevan lainnya dilakukan oleh Sari, et al (2020) yang menyatakan bahwa lembar kerja peserta didik menggunakan model project based learning dinyatakan layak terpenuhinya aspek kevalidan, praktikalitas dan efektivitas. Penelitian sejalan oleh Arsana \& Sujan (2021) bahwa pengembangan lembar kerja peserta didik berbasis proyek memenuhi kriteria kelayakan untuk digunakan guru sebagai bahan ajar sehingga menciptakan suasana pembelajaran yang aktif, kreatif dan inovatif. 
6208 Pengembangan Lembar Kerja Peserta Didik (LKPD) Berbasis Proyek pada Materi Siklus Air Kelas V Sekolah Dasar - Arie Widya Murni, Fajar Nur Yasin

DOI: https://doi.org/10.31004/basicedu.v5i6.1696

\section{KESIMPULAN}

Hasil validasi lembar kerja peserta didik (LKPD) berbasis proyek pada materi siklus air kelas 5 sekolah dasar dinyatakan sangat layak digunakan dalam pembelajaran. Hal ini sesuai hasil penilaian validasi oleh 2 orang terkait LKPD yang dikembangkan mencapai 3,75 dengan kategori sangat valid, hasil validasi materi 3,78 dengan kategori sangat valid, validasi RPP memperoleh nilai 3,73 dengan kategori sangat valid, dan lembar tes hasil belajar memperoleh nilai 3,56 dengan kategori sangat valid.

Kepraktisan lembar kerja peserta didik (LKPD) berbasis proyek pada materi siklus air kelas 5 sekolah dasar diukur dari respon penilaian guru terhadap LKPD yang dikembangkan memperoleh rata-rata persentase 97\% dengan kategori sangat baik, keterlaksanaan pembelajaran pertemuan I memperoleh persentase $75 \%$ dan pertemuan II memperoleh persentase 94\% dengan kategori terlaksana baik, sedangkan aktivitas anak pertemuan I memperoleh persentase $77 \%$ dan pertemuan II memperoleh persentase $94 \%$ dengan kategori aktif. Dengan kata lain, bahan ajar elektronik berbasis saintifik telah memenuhi syarat kepraktisan.

Keefektifan lembar kerja peserta didik (LKPD) berbasis proyek pada materi siklus air kelas 5 sekolah dasar dilihat dari nilai n-gain sebesar 0,67 dengan kategori sedang dan dianalisis menggunakan uji t dengan hasil perhitungan pretest yaitu nilai $t_{\text {hitung }}$ sebesar 1,468 dengan signifikan $0.147>0,05$, berarti tidak ada perbedaan hasil belajar. Sedangkan hasil penghitungan posttest menunjukkan bahwa pada penelitian ini diperoleh nilai $t_{\text {hitung }}$ sebesar 3,665 dengan signifikan sebesar $0.001<0.05$. Berdasarkan hasil tersebut, dapat dikatakan bahwa terdapat perbedaan hasil belajar dengan menggunakan lembar kerja peserta didik (LKPD) berbasis proyek siswa kelas V sekolah dasar. Dengan demikian, penerapan lembar kerja peserta didik (LKPD) berbasis proyek pada materi siklus air efektif digunakan dalam pembelajaran.

\section{DAFTAR PUSTAKA}

Amini, R., Setiawan, B., Fitria, Y., \& Ningsih, Y. (2019). The Difference Of Students Learning Outcomes Using The Project-Based Learning And Problem-Based Learning Model In Terms Of Self-Efficacy. Journal Of Physics: Conference Series, 1, 1-7. Https://Doi.Org/10.1088/1742-6596/1387/1/012082

Aristiadi, H., \& Putra, R. R. (2018). Pengaruh Penggunaan Lembar Kerja Peserta Didik (Lkpd) Berbasis Proyek Terhadap Hasil Belajar Peserta Didik Pada Konsep. Bioedusiana, 3(2), 77-84. Https://Doi.Org/10.34289/277886

Arsana, I. W. O. K., \& Sujan, I. W. (2021). Pengembangan Lembar Kerja Peserta Didik (Lkpd) Berbasis Project Based Learning Dalam Muatan Materi Ips. Jurnal Ilmiah Pendidikan Dan Pembelajaran, 5(1), 134-143. Https://Doi.Org/10.23887/Jipp.V5i1.32817

Astutik, S., \& Prahani, B. K. (2018). The Practicality And Effectiveness Of Collaborative Creativity Learning (Ccl) Model By Using Phet Simulation To Increase Students' Scientific Creativity. International Journal Of Instruction, 11(4), 409-424. Https://Doi.Org/10.12973/Iji.2018.11426a

Aunurrahman. (2009). Belajar Dan Pembelajaran. Alfabeta.

Awang, I. S. (2015). Kesulitan Belajar Ipa Peserta Didik Sekola Dasar. Vox Edukasi, 6(2), 108-122. Https://Doi.Org/10.31932/Ve.V6i2.106

Borg, W. R., \& Gall, M. (1983). Education Research: An Introduction. Longman Inc.

Branch, R. M. (2010). Instructional Design: The Addie Approach. In Instructional Design: The Addie Approach. Springer. Https://Doi.Org/10.1007/978-0-387-09506-6

Eggen, P., \& Kauchak, D. (2021). Strategi Dan Model Pembelajaran. Index.

Fannie, R. D., \& Rohati. (2014). Pengembangan Lembar Kerja Siswa (Lks), Poe(Predict, Observe, Explain), Program Linier Matematika. Jurnal Sainmatika, 8(1), 96-109. 

Sekolah Dasar - Arie Widya Murni, Fajar Nur Yasin DOI: https://doi.org/10.31004/basicedu.v5i6.1696

Hairunisa, H., Hakim, A. R., \& Nurjumiati, N. (2019). Studi Pengaruh Model Pembelajaran Berbasis Proyek (Project Based Learning) Terhadap Kreativitas Mahasiswa Program Studi Pgsd Pada Mata Kuliah Konsep Dasar Ipa. Jurnal Pendidikan Mipa, 9(2), 93-96. Https://Doi.Org/10.37630/Jpm.V9i2.190

Hake, R. R. (1999). Analyzing Change/Gain Scores. Indiana University.

Hakim, A. R., Hairunisa, H., \& Haris, A. (2020). Jurnal Pendidikan Mipa Pancasakti. Jurnal Pendidikan Mipa, 10(4), 94-101. Https://Doi.Org/10.37630/Jpm.V10i2.364

Krismawati, N. U. (2019). Pengembangan Bahan Ajar Penulisan Sejarah Berbasis Model Project-Based Learning. Indonesian Journal Of Social Science Education (Ijsse), 1(2), 156-170. Https://Doi.Org/Doi.Org/10.29300/Ijsse.V1i2.1905

Kristyowati, R. (2018). Lembar Kerja Peserta Didik (Lkpd) Ipa Sekolah Dasar Berorientasi Lingkungan. Prosiding Seminar Dan Diskusi Nasional Pendidikan Dasar 2018, 282-288. Http://Journal.Unj.Ac.Id/Unj/Index.Php/Psdpd/Article/View/10150

Mukti, F., Connie, C., \& Medriati, R. (2018). Pengembangan Lembar Kerja Peserta Didik (Lkpd) Pembelajaran Fisika Untuk Meningkatkan Kemampuan Berpikir Kreatif Siswa Sma Sint Carolus Kota Bengkulu. Jurnal Kumparan Fisika, 1(3), 57-63. Https://Doi.Org/10.33369/Jkf.1.3.57-63

Muskania, R. T., \& Wilujeng, I. (2017). Pengembangan Perangkat Pembelajaran Project-Based Learning Untuk Membekali Foundational Knowledge Dan Meningkatkanscientificliteracy. Jurnal Cakrawala Pendidikan, 6(1), 34-43. Https://Doi.Org/10.21831/Cp.V36i1.8830

Nieveen, N. (1999). Prototyping To Reach Product Quality. In Design Approaches And Tools In Education And Training. Https://Doi.Org/10.1007/978-94-011-4255-7_10

Noprinda, C. T., \& Soleh, S. M. (2019). Pengembangan Lembar Kerja Peserta Didik (Lkpd) Berbasis Higher Order Thinking Skill (Hots). Indonesian Journal Of Science And Mathematics Education, 2(2), 168 176. Https://Doi.Org/10.24042/Ijsme.V2i2.4342

Nur, M., \& Wikandari, P. R. (2000). Pengajaran Berpusat Kepada Siswa Dan Pendekatan Konstruktivis Dalam Pengajaran. Unesa University Press.

Purwanto. (2011). Evaluasi Hasil Belajar. Pustaka Pelajar.

Ratumanan, T. G. (2015). Inovasi Pembelajaran: Mengembangkan Kompetensi Peserta Didik Secara Optimal. Ombak.

Riduwan. (2013). Skala Pengukuran Variabel-Variabel Penelitian. Alfabeta.

Rofiah, N. H. (2014). Meningkatkan Keterampilan Proses Sains Da. Jurnal Pendidikan Sains Indonesia, 6(2), 253-271. Https://Doi.Org/10.14421/Al-Bidayah.V6i2.145

Sardiman. (2014). Interaksi Dan Motivasi Belajar Mengajar. Raja Grafindo Persada.

Sari, L., Taufina, T., \& Fachruddin, F. (2020). Pengembangan Lembar Kerja Peserta Didik (Lkpd) Dengan Menggunakan Model Pjbl Di Sekolah Dasar. Jurnal Basicedu: Journal Of Elementary Education, 4(4), 813-820. Https://Doi.Org/10.31004/Basicedu.V4i4.434

Setyowati, D., Mustaji, M., \& Subroto, W. T. (2018). Pengembangan Lembar Kerja Peserta Dengan Menggunakan Model Pembelajaran Berbasis Proyek Dalam Mata Pelajaran Ips Bagi Siswa Kelas Iv Sekolah Dasar. Jurnal Review Pendidikan Dasar: Jurnal Kajian Pendidikan Dan Hasil Penelitian, 4(2), 715-725. Https://Doi.Org/10.26740/Jrpd.V4n2.P715-725

Sugiyono. (2012). Statistika Untuk Penelitian. In Alfabeta: Bandung. Alfabeta.

Susiloningsih, E. (2015). Lembar Kerja Siswa Berbasis Kontekstual Dalam Pembelajaran Subtema "Aku Bangga Dengan Daerah Tempat Tinggalku." Jurnal Inovasi Sekolah Dasar, 2(2), 100-106. Https://Doi.Org/10.36706/Jisd.V2i2.8615 
6210 Pengembangan Lembar Kerja Peserta Didik (LKPD) Berbasis Proyek pada Materi Siklus Air Kelas V Sekolah Dasar - Arie Widya Murni, Fajar Nur Yasin

DOI: https://doi.org/10.31004/basicedu.v5i6.1696

Tasci, B. G. (2015). Project Based Learning From Elementary School To College, Tool: Architecture. Procedia - Social And Behavioral Sciences, 186(May), 770-775. Https://Doi.Org/10.1016/J.Sbspro.2015.04.130

Uno, H. B. (2010). Model Pembelajaran: Menciptakan Proses Belajar Mengajar Yang Kreatif Dan Efektif. Bumi Aksara.

Zulkurnia, D., Sowiyah, S., \& Jaya, M. T. B. (2017). Pengembangan Lkpd Berbasis Proyek Pada Siswa Kelas V Sd Muhammadiyah Kota Metro. Jurnal Pedagogi, 5(18), 2-12. 